Aleksandra Kruk

Łódź

\title{
PRZYWÓDZTWO GUIDO WESTERWELLE W WOLNEJ PARTII DEMOKRATYCZNEJ
}

Polityk urodził się w 1961 roku w Nadrenii Północnej Westfalii. Ze względu na jego wytrwałość mówiono, że „Nadreńczyk ma duszę Prusaka” ${ }^{\prime}$. Wyrastał $\mathrm{w}$ „mieszczańskim, choć niekonwencjonalnym domu”, nazywanym willą „Kunterbunt” (,groch z kapustą") $)^{2}$. Jego rodzice rozwiedli się w latach sześćdziesiątych, chłopiec miał wtedy 8 lat. Guido wspominał, że był to dla niego "trudny czas". Wychowaniem dzieci zajął się jego ojciec Heinz. Po pracy, przy obiedzie prowadził rozmowy z synami. Guido miał dobre relacje, podobnie jak jego bracia, z matką Eriką (z wykształcenia prawnikiem). Szczególnie przywiązał się do brata Kai. Uczęszczał do szkoły realnej, jednak dzięki poprawie mógł uczyć się w cieszącym się uznaniem gimnazjum Ernsta Moritza Arndta w Bonn. W szkole pokazał, że potrafi być „,urzędnikiem w swojej sprawie”. Interesował się sztuką w szkole i dlatego nauczyciele zachęcali, by ukończył studia artystyczne. Westerwelle do dzisiaj lubi malować, zbiera również obrazy współczesnych twórców - Tima Eitela i Norberta Bisky'ego ${ }^{4}$. W młodym wieku weekendy spędzał wyjeżdżając $z$ ojcem i kolegami ${ }^{5}$. Był niezwykle towa-

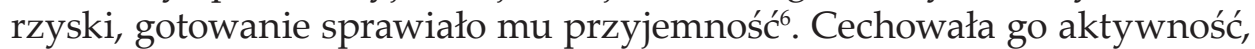
lubił dzielić się swoimi poglądami. Opinię - protest na temat kary śmierci opublikował w 1979 roku w szkolnej gazecie „Ventil”. Po złożeniu egzaminu dojrzałości, studiował prawo w Bonn. Obronił pracę doktorską na temat uregulowań prawnych dotyczących bezrobotnych ${ }^{7}$.

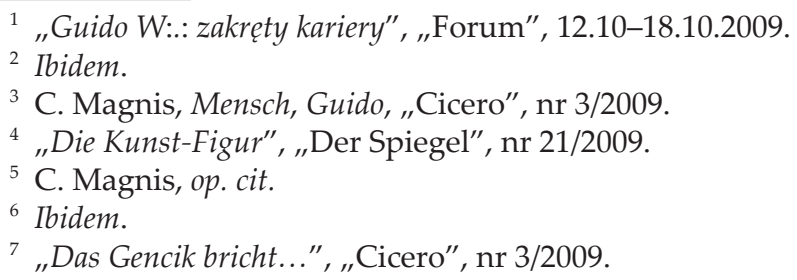


Zainteresowanie polityką przyszło później, dopiero w 1980 roku, chociaż w domu wiele dyskutowano np. o sprawach społecznych, o niesprawiedliwości. Wtedy też uczestniczył w Bonn, w hali Beethovena, w spotkaniu będącym elementem kampanii wyborczej. Obecni byli liderzy FDP: Hans-Dietrich Genscher, Otto Graf Lambsdorff, a Westerwelle był tam $\mathrm{w}$ towarzystwie swojego przyjaciela Wernera Hümmerlicha ${ }^{8}$. HansaDietricha Genschera Westerwelle nazywał swoim politycznym mentorem i mistrzem. Twierdził: „Hans-Dietrich Genscher to wielki wzór”9. Spośród wielu partii politycznych wybrał FDP, bo odpowiadały mu założenia programowe tej partii. Zwracał uwagę, żeby nie dookreślać niemieckiego liberalizmu słowami socjalny, ordoliberalny, prawicowoliberalny. Liberalizm nie potrzebuje takich dookreśleń-podkreślał. „Liberalizm to nie jest wolność od odpowiedzialności, ale wolność do odpowiedzialności, do odpowiedzialności za siebie samego i za następnych"10.

„SPD była dla niego przestarzała - oparta na walce klas. Zieloni „głęboko nietolerancyjni" i Unia z kandydatem na urząd kanclerski Franzem Josefem Straußem „po prostu tylko parafiańska”. Jego etos osiągnięć i jego seksualna tożsamość, jego bycie innym, obudziło w nim zainteresowanie liberalizmem"11.

Współpracę z FDP rozpoczął od młodzieżówki. W wieku 33 lat został sekretarzem generalnym. Działo się to w trudnym dla liberałów 1994 roku, czasie wielu klęsk wyborczych ${ }^{12}$. Westerwelle, za sprawą Kinkela, zastąpił sekretarza generalnego Wernera Hoyera. W roli sekretarza generalnego cechowała go „błyskotliwość i [...] zdolność [...] skuteczność medialna... był ciągle obecny"13.

Gdy rok później, podczas zjazdu w Moguncji w czerwcu 1995 roku, przewodniczącym został Wolfgang Gerhardt, Westerwelle nadal pełnił zadania sekretarza generalnego. Natomiast Klaus Kinkel zrezygnował z przywództwa w partii, gdyż był krytykowany za porażki wyborcze w 1994 roku. Był to tzw. superrok wyborczy w historii RFN ze względu na liczbę odbywających się wyborów. FDP nie przekroczyła m.in. 5\% progu poparcia i nie była reprezentowana w Parlamencie Europejskim. Liberałom zarzucano słabość programu, brak celu. G. Westerwelle odebrał zjazd w Moguncji jako krok w kierunku odnowy personalnej. Był zadowolony, że w prezydium zasiadło siedmiu nowych reprezentantów. Podkreślił,

${ }^{8}$ F.A. Mayer, Waren Sie ein Rebell?, "Cicero", nr 3/2009.

9 "Interview mit Bundesaußenminister Guido Westerwelle”, „Bild”, 07.11.2009.

${ }^{10}$ F. A. Mayer, op. cit.

${ }^{11}$ M. Sattar, „....und das bin ich! Guido Westerwelle. Eine politische Biographie, München 2009, s. 26.

${ }^{12}$ H. Vorländer, Die FDP im vereinten Deutschland, [w:] W. Woyke, Parteien und Parteiensystem in Deutschland, Schwalbach 2002, s. 46-48.

${ }_{13}$ "Auf der gelben Achterbahn", "Cicero", nr 3/2009. 
że zjazd scalił partię oraz deklarował, że ma wizję jej odnowy. Zależało mu na opracowaniu koncepcji aktywizacji członków partii i by ta sprawa została przedyskutowana na zjeździe partii w 1996 roku w Karlsruhe. Zaprzeczał, że FDP istnieje tylko po to, by utrudnić istnienie czerwono-zielonej koalicji. Uważał, że istotne jest propagowanie liberalnych wartości, a żadna partia poza FDP tego nie czyni. Krytykował inne partie i apelował o niezależność poglądów wśród liberałów ${ }^{14}$. O przywództwo w partii Westerwelle konkurował z liberałem, działaczem z Północnej Nadrenii-Westfalii, Jürgenem Möllemannem, który doczekał się określenia „niemiecki Heider".

Ważne sprawy, które Westerwelle podnosił po 1995 roku w publicznych działaniach to podwójne obywatelstwo, nowe technologie, podatki. Zdaniem Westerwelle podczas gdy amerykańskiej mentalności bliskie jest posiadanie dobrotliwego „wujka Sama”, który daje wiele swobody swoim bliskim ${ }^{15}$. Niemcy uważają, że mają „ojca-państwo”. Personifikacją potomstwa niemieckiego "ojca państwa” są "dzieci-niemieckie Michały”, którym przypisywał naiwność16. Westerwelle twierdził, że niemiecki „ojciec-państwa” posiada większy autorytet niż amerykański „wujek Sam”. Westerwelle woli liberalne społeczeństwo od stereotypowych niemieckich Michałów. Od obywateli oczekiwał odpowiedzialności i samodzielności. Chciał śmierci „ojca państwa”, ponieważ uważał, że niemieccy patrioci powinni budować państwo „skromne"17.

Propagował myśl, że "gospodarka rynkowa jest moralna" i jest przesłanką do kształtowania społeczeństwa obywatelskiego. Powtarzał wypowiedź Otto Grafa Lambsdorffa, że bez gospodarki rynkowej nie będzie demokratycznej wspólnoty. Popierał gospodarkę rynkową jako jedyny system gospodarczy, który jest „kompatybilny z ludzką naturą”. Zdaniem Westerwelle ludzie realizując własne cele życiowe - osobisty dobrobyt i dobry standard życiowy dla rodziny - przyczyniają się do sukcesu zbiorowości. Swój pogląd poparł opinią Ulricha Becka ", bez ja żadne my" oraz stwierdził "gospodarka rynkowa jest ludzka"18. Aby przekonywać do swoich idei, odwoływał się do biografii innych polityków. Jego zdaniem, Winston Churchill, John F. Kennedy, Ronald Reagan, Bill Clinton

${ }^{14}$ G. Westerwelle, Die eigenen Stärken stärken, „Liberal”, nr 3/1995, s. 10-12.

${ }^{15}$ Według definicji: (ang. Uncle Sam), przydomek oraz postać symbolizująca USA (rząd, państwo); termin utworzony od skrótu U.S. (United States), używany od czasu wojny 1812 roku, http://encyklopedia.wp.pl/encid,1751002,name,wuj-sam,haslo. html?ticaid=1f2da

${ }^{16}$ G. Westerwelle, Neuland Einstieg in einen Politikwechsel, München-Düsseldorf 1998, s. 89-93.

\footnotetext{
${ }^{17}$ Ibidem, s. 93.

${ }^{18}$ Ibidem, s. 143-149.
} 
rozumieli, że „z celem w oczach cel jest lżejszy”19, „zadaniem rządu jest nie tylko zarządzać, lecz kształtować" ${ }^{\prime 20}$. Odróżniał rolę wizjonerów od innych ról społecznych. Jego zdaniem zwykli ludzie formułują zarzuty, że politycy są krótkowzroczni i nie dostrzegają problemów. Wizjonerzy, tacy jak Ludwig Erhard musieli przebijać się ze swoimi zamiarami. Do wzorów politycznych Westerwelle zaliczył Ludwiga Erharda i Willy Brandta. O ojcu cudu gospodarczego napisał: „konsekwencja, z którą wbrew wielkim oporom forsował [swoje cele dod. A. Kruk] jest [...] wzorowa"21. W. Brandta cenił nie tylko za zdolności przywódcze. Uważał, że trafne były jego hasła „więcej demokracji ważyć” oraz „kto jutro chce żyć bezpiecznie, musi dzisiaj walczyć reformami”22. Wyrażał się również z uznaniem o polityce Helmuta Kohla w 1982 roku. Uważał, że Kohl miał świadomość, że społeczeństwo jest gotowe na wysiłek i poniesienie ofiar, jeśli obywatele odczują, że są prowadzeni przez przywódców politycznych w prawidłowym kierunku"23. Krytykował natomiast Kohla za to, że nie wytłumaczył Niemcom, iż zjednoczenie wymaga wyrzeczeń. Zdaniem Westerwelle John F. Kennedy zasłynął postulatem „nie pytaj, co państwo może zrobić dla ciebie, lecz co ty możesz zrobić dla państwa", a Winston Churchill ofiarował narodowi "krew, pot i łzy”. Kohl natomiast obiecywał "kwitnące krajobrazy”, nie tłumacząc jak je zdobywać24.

Westerwelle rozróżniał "dobrych ludzi" i „ludzi rozdających dobra". Ludzie rozdający dobra to politycy i działacze w organizacjach pozarządowych, którzy przedstawiają się jako reprezentanci tak zwanych „małych ludzi". Wymienił dla przykładu socjaldemokratów: Ritę Süßmuth, Norberta Blüma, Rudolfa Dresslera, Heinera Geißlera i Johannesa Raua. Ludzie ci ,jjako politycy rozdają podatki [...] prowadzą politykę subwencyjną i podatkową zgodnie z zasadą pełnej kasy"25. Podkreślał, że koszt takiej polityki ponosi społeczeństwo, które płaci podatki. „Ludzie rozdający dobra" nie zmierzają do zaprzestania polityki rozdawniczej i takie działanie nazywał „cichą tyranią"26. Westerwelle był przeciwnikiem podatku solidarnościowego. Krytykował „ludzi rozdającym dobra” za to, że wprowadzają społeczeństwo w błąd operując "nowymi pojęciami walki", które znajdują posłuch wśród bezrobotnych. "Nowe pojęcia walki” to globalizacja, ucieczka kapitału, praca na czarno, lepiej zarabiający, drobne stosunki zatrudnienia"27. Jego zdaniem polityka rozdawnictwa przyczy-

\footnotetext{
19 Ibidem, s. 18.

20 Ibidem.

${ }^{21}$ Ibidem, s. 19.

${ }^{22}$ Ibidem.

${ }^{23}$ Ibidem, s. 20.

${ }^{24}$ Ibidem, s. 54.

${ }^{25}$ Ibidem.

26 Ibidem, s. 24.

27 Ibidem, s. 25.
} 
nia się do ubożenia społeczeństwa, skutkuje zmęczeniem społeczeństwa partiami (Parteinverdrossenheit”), następnie zmęczeniem polityką („,Politikverdrossenheit”), a w konsekwencji zmęczeniem demokracją („Demokratieverdrossenheit" $)^{28}$.

Westerwelle prezentował się jako przeciwnik „nacjonalizacji myślenia" i oczekiwania, że państwo będzie rozwiązywało problemy obywateli. W przekonaniu G. Westerwelle państwo powinno być w rękach obywateli, a nie instytucji. Twierdził, że zbyt wysokie podatki sprzyjają wzrostowi korupcji. Zbyt wiele państwa osłabia społeczeństwo, zmniejsza mobilność, sprawność działania ${ }^{29}$. Jego zdaniem w Niemczech lat dziewięćdziesiątych „panowała demokracja podobania się”, co było wyrazem szkodliwości i nieodpowiedzialności oraz „następstwem upaństwowienia polityki”30. „Polityka podobania się" nie sprzyja przeprowadzenie reform w państwie, „nie ma kierunku i celu. Z nią na końcu nikt nie wygra”"31.

O państwie socjalnym pisał: „własna odpowiedzialność zamiast państwa, praca zamiast opieki, równość szans zamiast równości wyników muszą stać się celami nowej polityki socjalnej"32.

Zdaniem Westerwelle „porządek, równość i wolność to świat pierwotny każdej humanistycznej wspólnoty" ${ }^{\prime \prime 3}$. Zaznaczał, że tradycyjnie porządek jest kojarzony z prawica, równość z lewica, wolność przeznaczona jest dla liberałów. Jednak dla liberałów porządek i równość są istotne. Nie równość wyników, ale równość szans była dla niego wartością ${ }^{34}$. „Liberalizm nie jest przywilejem określonej grupy dużo zarabiających, określonej grupy zawodowej, o specjalnej strukturze wieku czy wyznaniu [...] to specjalna mentalność", "stosunek do życia”, którego skutkiem jest poczucie odpowiedzialności za następnych”35. „Wolność to nie jest wolność możliwości spania pod mostami, nie jest to wolność Robinsona Crusoe, w której nikt nie musi na nikogo zważać. Wolność nie jest społecznym odosobnieniem, egoizmem i brakiem spojenia (....) indywidualna wolność nie jest [...] przeciwko poczuciu wspólnoty"36.

Westerwelle pytany o rolę rodziny odpowiadał, że „rodziny potrzebują specjalnego wsparcia" ${ }^{137}$. Jego zdaniem inwestycja w rodzinę to inwestycja

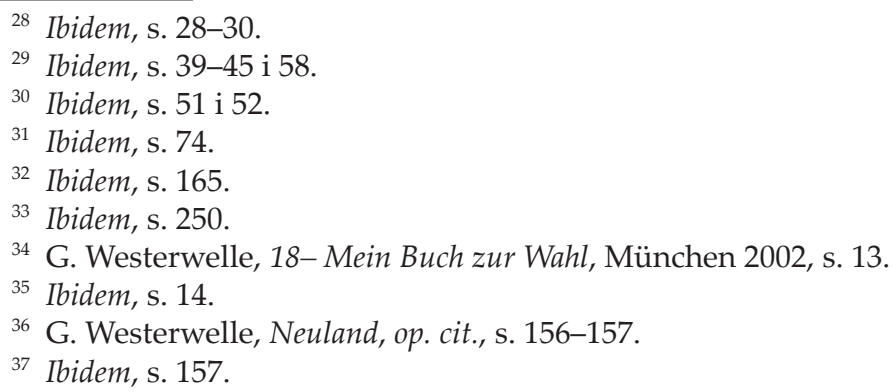


w przyszłość. Wyrażał poparcie dla partnerstwa tej samej płci, a sam późno przyznał się opinii publicznej do związku z mężczyzną ${ }^{38}$.

Westerwelle, zaliczany do pokolenia yuppie, wiele uwagi poświęcał pokoleniu 68. Lata siedemdziesiąte to z jego perspektywy czas rewolty studenckiej, antyautorytatywnego wychowywania, rządowej polityki zakazu wykonywania zawodu (Berufsverbot) aktywizacji społeczeństwa $\mathrm{w}$ organizacjach pokojowych, kobiecych i innych ${ }^{39}$. Opozycja pozaparlamentarna (APO) była reakcją na „polityczny i społeczny klimat [...] czasu” - „materializm lat pięćdziesiątych. Pokolenie końca lat sześćdziesiątych miało już inne problemy, od wojny minęło dwadzieścia lat. To pokolenie żyło $\mathrm{w}$ atmosferze zimnej wojny, wydarzeniami w Wietnamie i Iranie. APO było reakcją na „konserwatywne zesztywnienie”. A następstwem tego ruchu stał się postmaterializm lat osiemdziesiątych. W latach dziewięćdziesiątych pokolenie APO przeistoczyło się w ruch „APO babć i dziadków”. Pokolenie APO nie hołdowało wartościom typu „osiągnięcia, kariera, Bessersein". Zdaniem polityka obecnie młodzieży zależy na zwiększeniu szans osiągania sukcesów. Z nowym pokoleniem pojawiają się nowe idee. Ruch APO powinien ustąpić młodszym pokoleniom. Opór byłby zdaniem Westerwelle tak błędny, jak „kampania Axela Springera” przeciwko pokoleniu $1968^{40}$.

Pokolenie lat siedemdziesiątych nazywał "Verbrauchsgeneration" („skonsumowana generacja”). Reprezentanci tej generacji byli w jego oczach ludźmi żyjącymi na koszt następnych generacji i korzystającymi z osiągnięć wcześniejszych pokoleń. Westerwelle jest przeciwnikiem „demokracji podobania się"4t. Wiele refleksji polityk kierował w stronę imigrantów. Protestował przeciwko nietolerancji, polityce wykluczenia, krytykował "gettoizację". Podobnie jak jego mistrz H.-D. Genscher podkreślał znaczenie polityki na rzecz ochrony środowiska ${ }^{42}$.

W 1996 roku dał się zauważyć wzrost siły FDP. Partia odnotowała sukcesy w landach, zdobyła w Badenii Wirtembergii 9,6\% poparcia, w Nadrenii Palatynacie 8,9\%, w Szlezwik Holsztynie 5,7\%. Krokiem w kierunku poprawy kondycji partii było uchwalenie w 1997 roku „Zasad w Wiesbaden - dla liberalnego społeczeństwa". Był to program działań na rzecz odpowiedzialności, różnorodności, postępu, który $\mathrm{w}$ rezultacie miał prowadzić do kształtowania społeczeństwa obywatelskiego w RFN ${ }^{43}$.

38 Ibidem, s. 157-159.

${ }^{39}$ Ibidem, s. 32.

${ }^{40}$ Ibidem, s. 33-37.

${ }^{41}$ G. Westerwelle, Korsettstangen für den schlanken Staat, „Liberal”, nr 1/1996, s. 11-12.

${ }^{42}$ G. Westerwelle, op. cit., s. 204.

${ }^{43}$ J. Dittberner, Sozialer Liberalismus. Ein Plädoyer, Berlin 2008, s. 81 i 87-88; „Wiesbadener Grundsätze. Für die liberale Bürgergesellschaft beschlossen auf dem Bundesparteitag 
Porażka FDP podczas wyborów parlamentarnych 27 września 1998 r. stanowiła dla Westerwelle ważną cezurę. Jego partia utraciła władzę, gdyż „rząd był zużyty"44. Mimo że FDP nie znalazła się u władzy, to jednak 6,2\% głosów pozwoliło liberałom uczynić z parlamentu opozycyjną arenę. Ten czas Westerwelle traktował jak etap odnowy. Zwracał też uwagę, że dla FDP przyszedł czas zmiany pokoleniowej ${ }^{45}$.

W dniach 28-30 maja 1999 roku podczas zjazdu partii w Bremie poparta została strategia równego oddalenia od CDU i SPD. Osłabienie chadecji „aferą Kohla” (tj. zarzutami o nielegalne finansowanie partii) wpłynęło na poprawę pozycji FDP. W Bremie przewodniczącym został Wolfgang Gerhardt, a jego zastępcami Rainer Brüderle z Nadrenii Palatynatu, Cornelia Pieper z Saksonii Anhalt, Walter Döring z Badenii-Wirtembergii. Guido Westerwelle pozostał przy funkcji sekretarzem generalnym.

14 maja 2000 roku Jürgen Möllemann odniósł sukces w wyborach do Landtagu w Nadrenii Północnej-Westfalii. Poparcie podczas wyborów dla liberałów wzrosło z 4,0\% do 9.8\%. Ten dobry wynik był świętowany podczas zjazdu partii 16 i 17 lipca w Norymberdze. J. Möllemann opowiedział się wtedy za celem zdobycia $18 \%$ poparcia w zbliżających się wyborach parlamentarnych. Postulował, aby zdobyć o $10 \%$ więcej głosów poparcia niż w Nadrenii Północnej-Westfaliii ${ }^{46}$.

Podczas zjazdu FDP w dniach 16 i 17 czerwca 2000 w Norymbergii przemawiali Wolfgang Gerhardt, Jürgen Möllemann, Rainer Brüderle, Guido Westerwelle oraz Carl-Ludwig Thiele. Sekretarz generalny Westerwelle wystąpił z hasłem: „Więcej demokracji” i wypowiadał się na temat potrzeby budowania społeczeństwa informacyjnego: „społeczeństwo informacyjne popiera różnorodność, elastyczność, mobilność. Ono potrzebuje większej niezależności ludzi. Ono potrzebuje [...] indywidualizmu. Potrzebuje myślących, gotowych do działania zespołowego, odpowiedzialnych ludzi. Potrzebuje liberalnego obrazu człowieka"47. Podkreślił rolę młodych ludzi: „młoda generacja nie jest generacją bez przyszłości, lecz jest gotową do wysiłku, [...] tolerancyjną i otwartą na świat generacją. My Wolni Demokraci jesteśmy naturalnie związani z tą młodą generacją"48. Istnieje walka o wyborców między liberałami a Zielonymi: „Duell między Zielonymi i FDP rozstrzygnie się przede wszystkim wśród młodego

der F.D.P. am 24.05.1997 in Wiesbaden", http://www.fdp-bw.de/regional/dokumente. php?kvid=Hohenlohe

${ }^{44}$ G. Westerwelle, $18 \ldots$, op. cit., s. 7.

${ }^{45}$ Ibidem.

${ }^{46}$ U. Leuschner, op. cit., s. 297-303.

${ }^{47}$ G. Westerwelle. Mehr Demokratie wagen - Wider die Verkastung der Politik, http:// www.fdp-bundespartei.de/files/363/rede_westerwelle.pdf

${ }^{48}$ Ibidem. 
pokolenia"49. Wrogowie liberałów to Zieloni w Niemczech Zachodnich i PDS w Niemczech Wschodnich. Społeczeństwo jest silne, gdy jest odpowiedzialne, a siłą społeczeństwa jest małżeństwo i rodzina ${ }^{50}$.

Podczas zjazdu partii w Düsseldorfie, który obradował od 4 do 6 maja 2001 roku, Guido Westerwelle, zdobywając poparcie rzędu 88,91\%, został przewodniczącym. Liberałowie przystali wtedy na „rozwiązanie tandemowe" - Westerwelle miał być przewodniczącym, a W. Gerhardt przewodniczącym frakcji ${ }^{51}$. Wybrani zostali także trzej wiceprzewodniczący Rainer Brüderle 88,87\%, Jürgen W. Möllemann 66,25\%, Walter Döring $50,70 \%$. Skarbnikiem został Günter Rexrodt 78,72\%, sekretarz generalną Cornelia Pieper, która uzyskała 74,58\% poparcia ${ }^{52}$. W mowie podsumowującej G. Westerwelle zwrócił uwagę na ukonstytuowanie się nowej władzy w partii oraz gotowość realizacji nowej strategii. Zadeklarował „pożegnanie z obrazem FDP według motta „mała ale fajna”. Scharakteryzował liberałów jako indywidualistów, którzy potrafią pracować zespołowo. Zaznaczył, że FDP nie będzie utożsamiana "tylko z określoną grupą wiekową czy zawodową", czy majątkową. Politycy FDP kierują swój program do wszystkich Niemców. Westerwelle w Düsseldorfie bronił formuły „Spaßgesellschaft", gdyż niesie ona optymizm i radość życia. Zadeklarował chęć realizacji przygotowanej przez Fritza Georgena kampanii wyborczej. FDP nazywał „partią dla wszystkich w państwie”, w której „największym surowcem Niemców" jest oświata. Priorytetami czynił wiedzę, równość szans w zdobywaniu wykształcenia, ponadto „własność prywatną, osiągnięcia, konkurencję"53.

Atak na World Trade Center 11 września 2001 roku traktował Westerwelle jako punkt zwrotny w niemieckiej polityce zagranicznej. Jednak uważał, że najważniejszy głos wobec konfliktu z Irakiem powinna mieć Organizacja Narodów Zjednoczonych, a nie pojedyncze państwa, choćby mocarstwa.

Kampania wyborcza do Bundestagu w 2002 roku miała być profesjonalna. To Fritz Georgen opracował strategię 18. Liberałowie ubiegali się o 18\% poparcie w społeczeństwie. FDP prezentowała się jako partia całego narodu. Jednak młodzież stanowiła ważną grupę docelową w kampanii, która była wzorowana na wyborach do Landtagu w Nadrenii Północnej Westfalii, prowadzonej w myśl sloganów: „więcej pieniędzy na oświatę”. „Nadrenia Północna Westfalia potrzebuje tempa. Möllemann”. Liberało-

${ }^{49}$ Ibidem.

${ }^{50}$ Ibidem.

51 J. Dittberner, Die FDP, Geschichte, Personen..., s. 112; U. Leuschner, op. cit., s. 306.

${ }^{52} \mathrm{http} / / / \mathrm{www} . f d p-b u n d e s p a r t e i . d e / w e b c o m /$ show_page.php?wc_c=658\&wc_id=1

${ }_{53}$ G. Westerwelle, Anspruch Freiheit, „Liberal”, nr 6/2001, s. 3-5; U. Leuschner, op. cit., s. 309. 
wie stworzyli strony internetowe www.brauchttempo.de i www.liberalesnetz-de i reklamowali się umieszczając na dużych powierzchniach plakaty oraz wykupując spoty podczas seansów w kinie ${ }^{54}$. Do realizacji celów wyborczych potrzebne było porozumienie czołowych polityków w partii (Rainer Brüderle, Patrick Döring, Wolfgang Gerhardt, Jürgen Möllemann i Guido Westerwelle). Strategia została uzgodniona na zjeździe w Düsseldorfie w 2001 roku. Priorytetem w programie liberałowie uczynili oświatę i modernizację społeczeństwa. Westerwelle tłumaczył „dobre kształcenie kosztuje: złe jeszcze więcej”55. Czas przemysłu powinien być zastąiony przez epokę nauki. Wskazywał na rolę pracowników naukowych ${ }^{56}$. Promował elastyczność, mobilność, samodzielność ludzi, indywidualność, otwarcie na świat, tolerancja, wolność, walkę z populizmem, zapobieganie uprzedzeniom. Kampanii towarzyszyły hasła: „więcej nettto dla wszystkich”, „więcej oświaty dla wszystkich”, „więcej pracy dla wszystkich”, „więcej wolności we wszystkich obszarach" ${ }^{\prime \prime}$. Fritz Georgen stał się członkiem „Teamu 18" Westerwelle"58.

Podczas zjazdu w Mannheim w dniach 10-12 maja 2002 Westerwelle wybrany został kandydatem na kanclerza z ramienia FDP. Jego kandydaturę, jako alternatywę wobec G. Schrödera i Edmunda Stoibera, zaproponował honorowy przewodniczący Genscher ${ }^{59}$. Program wyborczy liberałów nosił nazwę „Program obywatelski 2002”60. Liberałowie opowiadali się za ratyfikacją konstytucji europejskiej, rozszerzeniem Unii Europejskiej, umacnianiem wspólnej polityki zagranicznej i bezpieczeństwa. Kampanię wyborczą cechował wysoki poziom personalizacji. Główny kandydat prezentował swoje atuty: młodość, otwartość, sprawność w działaniu, optymizm $^{\prime 61}$. FDP według strategii opowiada się za państwem prawa, socjalnej gospodarki rynkowej, oświaty. Szczególne znaczenie miało wykorzystanie w kampanii internetu. Fora dyskusyjne były szczególnymi instrumentami walki wyborczej ${ }^{62}$. "Westerwelle zamiast Pleitwelle (fali bankructw)”

${ }^{54}$ F. Georgen, Skandal FDP. Selbstdarsteller und Geschäftsmacher zerstören eine politische Idee, Köln 2004, s. 62-68.

${ }^{55}$ G. Westerwelle, op. cit., s. 23.

${ }^{56}$ F. Georgen, op. cit., s. 69.

57 Ibidem, s. 95.

${ }^{58}$ Ibidem.

59 „FDP ma po raz pierwszy kandydata na kanclerza”, http://kronika.sejm.gov.pl/miedzynarodowa.4/text $/ \mathrm{km} 14 . \mathrm{htm} \# \mathrm{~b} 16$

60 „Bürgerprogramm 2002. Programm der FDP zur Bundestagswahl 2002 beschlossen auf dem 53. Ord. Bundesparteitag vom 10. bis 12. Mai 2002 in Mannheim", http://www.nachhaltigkeit.info/artikel/boergerprogramm_2002_der_fdp_836.htm

${ }^{61}$ F. Georgen, op. cit., s. 95.

${ }^{62}$ S. Kapferer, Generation @und Politik. Internet bringt Wähler und Gewählte wieder zusammen, "Liberal”, nr 6/2001, s. 9-12. 
- było to modne hasło. Liberałowie w kampanii przypominali o znaczeniu uczuć, emocji, starali się pozyskać młodych ludzi. By zabiegać o wyborców Westerwelle wydał książkę „18-Mein Buch zur Wahl” i podróżował po Niemczech w żółtym guidomobiu. Jego popularność wzrosła, gdyż pokazał się wyborcom w programie „Big Brother”. Kampania była wzorowana na kampanii wyborczej w Nadrenii Północnej Westfalii ${ }^{63}$. FDP prezentowana była jako „Spaßpartei”. Kampania wyborcza z akcentami na wzór „Love Parade”, z muzyką techno zapisała się w pamięci. Ten styl w połączeniu z zarzutami o antysemityzm wobec członków FDP osłabił liberałów ${ }^{64}$. FDP borykała się z problemami, wiosną poparcie dla FDP sięgało 12\%, jednak później zaczęło spadać. Szczególnie zarzucano partii w związku z postacią Jamala Karsli antysemityzm. Jamal Karsli - Niemiec syryjskiego pochodzenia, który zasłynął z antysemickich i wrogich Izraelowi wypowiedzi najpierw należał do partii Zieloni. Zrezygnował z członkowstwa $\mathrm{w}$ tej partii, bo nie utożsamiał się z jej polityką wobec Izraela. Za namową popierającego palestyńskie ataki samobójcze przewodniczącego Towarzystwa Niemiecko-Arabskiego Jürgena Möllemanna zmienił przynależność na FDP. J. Karsli w swoich wystąpieniach domagał się, by społeczeństwo niemieckie poparło Palestyńczyków i wyraziło krytykę wobec polityki Izraela. Centralna Rada Żydów wyraziła oburzenie wobec szerzonych przez J. Karsliego poglądów. Politycy z FDP, w tym Hans-Dietrich Genscher zarządzali natomiast od Möllemanna, by ten zaprzestał popierać J. Karsliego ${ }^{65}$. Autorytet tego polityka ucierpiał również w kwietniu 2002 roku za sprawą Łzw. afery czipowej,- „, afery Möllemanna". Politykowi sprawującemu funkcję ministra gospodarki postawiono zarzut nielegalnego wspierania firmy - producenta czipów ${ }^{66}$.

Szanse liberałów osłabły tym bardziej, gdy istotnym tematem kampanii stała się powódź. Westerwelle domagał się zmniejszenia subwencji przeznaczonych dla górnictwa, by pozyskać pieniądze na pomoc ofiarom powodzi. To wpłynęło na zmniejszenie poparcia FDP, a wzrost wpływów kanclerza Schrödera. Podobnie wydarzenia w Iraku okazały się issues stanowiącymi o sukcesie wyborczym socjaldemokracji ${ }^{67}$. W kampanii najważniejszą walkę toczył duell Gerhard Schröder-Helmut Kohl. Afera Kohla osłabiła szanse chadecji ${ }^{68}$.

Liberałowie chcieli wrócić w wyniku wyborów z 22 września do władzy. Nie zadeklarowali na zjeździe w Berlinie 8 września, z którą partią

${ }^{63}$ H.-J. Beerfeltz, Die 18 und der Charakter der FDP, ,Liberal”, nr 9/2002, s. 5-11.

${ }^{64}$ U. Leuschner, op. cit., s. 309.

${ }^{65}$ F. Georgen, op. cit., s. 87; J. Trenkner, Chłopcy z zapałkami, http://www.tygodnik. com.pl/numer/276325/trenkner.html

${ }_{66}$ "Śmierć politycznego gracza”, ,Przegląd”, nr 24/2003.

${ }^{67}$ K. Bachmann, P. Buras, S. Płóciennik, Republika bez gorsetu, Wrocław 2005, s. 43-44.

${ }^{68}$ F. Georgen, op. cit., s. 69. 
chcieliby stworzyć koalicję, mimo takiej woli ze strony A. Merkel i Edmunda Stoibera. Guido Westerwelle argumentował: „Nie wystawimy przed wyborami do Bundestagu czeku in blanco ani chadecji, ani socjaldemokratom, ponieważ tylko jako samodzielna siła będziemy w stanie przeforsować zapowiadany zwrot w polityce" [...]. Nasze stanowisko koalicyjne brzmi: niższe podatki, bardziej elastyczny rynek pracy - odpowiadający interesom średnich przedsiębiorców - więcej pieniędzy na wykształcenie oraz mniej biurokracji”69.

Strategia $18 \mathrm{w}$ wyborach parlamentarnych poniosła porażkę. Liberałowie zdobyli 22 września 2002 roku 7,4\% poparcia. Znowu musieli pozostać w opozycji. SPD osiągając zbliżony do Chadecji wynik (38,5\%) porozumiała się Zielonymi i utworzyła rząd.

Guido Westerwelle uważa, że 2002 rok to jego „najniższy poziom”, a „miesiące przed wyborami w 2002 roku” nazwał „najbardziej rozczarowującymi w karierze. Źródło tej sytuacji wyjaśniał mgliście. O problemach z J. Möllemannem stwierdzał, że były "tragedią". Nie krytykował tez przyjętej wtedy strategii wyborczej, która zdaniem wielu obserwatorów była zbyt populistyczna. Jego buty z narysowaną na podeszwach liczbą 18 - symbolem walki wyborczej - trafiły do muzeum ${ }^{70}$.

W maju 2003 roku podczas zjazdu w Bremie Westerwelle utrzymał stanowisko przewodniczącego partii. Jednak poparcie, które otrzymał zmalało, sięgało 80\%. Zastępcą Westerwelle został Walter Döring ${ }^{71}$.

Dramatycznym wydarzeniem w historii liberałów była śmierć Jürgena Möllemanna. Ten krytykowany i wzbudzający kontrowersje polityk zabił się na spadochronie 5 czerwca 2003 roku. Spekulowano co do tej śmierci, bo tego samego dnia Bundestag odebrał politykowi immunitet poselski. Westerwelle wyraził współczucie jego rodzinie ${ }^{72}$.

Od 2003 roku Westerwelle był odpowiedzialny za wizję polityki liberalnej w FDP. W listopadzie 2003 roku, już z perspektywy opozycji, przedstawili liberałowie dokument "Za wolnym i fair społeczeństwem"73, w którym opowiedzieli się za reformą zarówno Niemiec, jak i FDP. Wychodząc z założenia, że dystrybucja dóbr nie zapewni wzrostu i dobrobytu oraz szkodzi następnym pokoleniom, liberałowie postulowali kształtowanie htm\#b17

${ }^{69}$ „FDP daży do władzy”, http://kronika.sejm.gov.pl/miedzynarodowa.4/text/km20.

70 "Ich bin nicht beleidigt", „Der Spiegel”, nr 11/2008.

71 "Dämpfer für Westerwelle”, http://www.sueddeutsche.de/politik/fdp-parteitag-inbremen-daempfer-fuer-westerwelle-1.317368

72 „Jürgen W. Möllemann”, Munziger-Archiv/Internat. Bograph. Archiv 38/03 p01618613; J. Piaseczny, Śmierć politycznego gracza, http://www.przeglad-tygodnik.pl/index.php?site=artykul\&id=4574; P. Cywiński, Pożegnanie z „Nullemanem, „Wprost”, 17.01.1993.

73 "Für eine freie und fair Gesellschaf" Für die freie und faire Gesellschaft"; Positionsschrift von Dr. Guido Westerwelle, MdB Bundesvorsitzender der FDP, Berlin, 3. November 2003. 
„społeczeństwa osiągnięćc (Erwirtschaftungsgesellschaft). Twierdzili, że najpóźniej w 2006 roku należy rozpocząć reformy zmierzające do uczynienia z RFN nowoczesnego państwa z silnym sektorem usługowym. Ważny element reform stanowiło budowanie społeczeństwa obywatelskiego w nawiązaniu do Tez z Wiesbaden ${ }^{74}$.

W maju 2004 roku Horst Kohler pokonał Gesine Schwan w wyborach prezydenckich. Wydarzenie to Westerwelle traktował jako ważną cezurę w swojej karierze i dostrzegał zbieżności między swoją sytuacją a karierą Angeli Merkel. Uważał, że sukces Kohlera przyspieszył karierę jego i liderki chadecji ${ }^{75}$.

Kampania do Europarlamentu w 2004 roku, której faworytką była Silvana Koch-Mehrin, przyniosła liberałom 6,1\% poparcia. Liberałowie mogli znowu zasiąść w Europarlamencie. Tym bardziej przed wyborami do Parlamentu Europejskiego postawa Westerwelle spotkała się z krytyką Waltera Scheela, H.-D. Genschera i K. Kinkela. Na brak zaangażowania przewodniczącego w kampanię do Europarlamentu narzekała kandydatka S. Koch-Mehrin ${ }^{76}$.

W maju 2005 roku Westerwelle apelował o koniec rządów czerwono-zielonej koalicji. Krytykował politykę gospodarczą rządu, obarczył winą za niski wzrost gospodarczy oraz rosnące bezrobocie, problemy oświatowe, słabość systemu socjalnego. Oskarżał Joschkę Fischera o brak wykształcenia oraz „lewicowy obraz świata - Pilność jest kołtuńska. Dyscyplina staromodna. Gotowość niesienia pomocy z wczoraj. Uprzejmość nudna. Ambicja zbyt stresująca. Sukcesy są tylko przypadkowe i równe"77. Podkreślał znaczenie polityki gospodarczej: „polityka przyjazna gospodarce nie jest przeciwko pracownikom, tylko jest dla pracowników". Zarzucał Zielonym: „Zieloni są partią postmaterialnej sytości. Zieloni są partią dobrobytu. Tylko bardzo bogaci mogą sprostać polityce Zielonych. Nasz kraj nie moż $^{78}$.Paradoksalnie spośród reprezentantów świata niemieckiej polityki Westerwelle jest często porównywany do Jürgena Möllemanna oraz Joschki Fischera ${ }^{79}$.

W programie FDP znalazły się „obniżenie podatków, redukcja biurokracji, reforma oświaty"80. Westerwelle podkreślał, że epoka przemysłu

${ }^{74}$ Ibidem.

75 "Gestörtes Verhältnis", „,Der Spiegel”, nr 40/2006.

76 "Gnaden gegen Guido", "Der Spiegel”, nr 19/2004.

77 "Rede von Dr. Guido Westerwelle auf dem 56. Ord. Bundesparteitag am 5. Mai 2005 in Köln", http://56.parteitag.fdp.de/files/23/BPT2005_RedeBV.pdf

${ }^{78}$ Ibidem.

${ }^{79}$ M. Sattar, op. cit., s. 8 I 11.

80 "Der Leichtmatrose",http://www.stern.de/politik/deutschland/534975.html 
oddała miejsce epoce wiedzy, a Internet to przyszłość, nowy sposób komunikacji ${ }^{81}$.

21 czerwca 2005 Gerhard Schröder złożył wniosek o votum zaufania do rządu. Wybory zostały zaplanowane na 18 września 2005 roku. Liberałowie przygotowali program: „Praca ma pierwszeństwo - program niemiecki $2005^{\prime \prime 82}$.

Guido Westerwelle po wyborach odrzucił propozycję G. Schrödera, by utworzyć koalicję socjaldemokratyczno-liberalną ${ }^{83}$.Był przeciwnikiem koalicji świateł drogowych (SPD, FDP, Zieloni). FDP najpierw prezentowała się jako „wymarzony partner" chadecji, jednak z czasem uważane za dobre relacje między Angela Merkel i Westerwelle uległy ochłodzeniu ${ }^{84}$.

Coraz bardziej zauważalna była płynność programów politycznych niemieckich partii, oceniano, że zarówno chadecja, jak i socjaldemokracja sięgały po kroki, które dotychczas przypisywano partiom lewicowym. Wybory z 2005 roku były tez odzwierciedleniem spadku poparcia partii, które dotychczas zyskiwały duże poparcie. Rosły w sile natomiast Partia Lewicy, Zieloni i Liberałowie. Narzekano, że reformy nie zostały wdrożone $z$ odpowiednim impetem.

W maju podczas zjazdu w Rostoku promował myśl „Niemcy mogą więcej". O wyniku wyborów parlamentarnych twierdził, że nowe rządy „będą drogie" niem podatków zgodnie z trzystopniową taryfą Hermanna Otto Solmsa (15\%, 25\%, 35\%). Jego zdaniem państwo musi realizować najważniejsze zadania, za takie uważał konsolidację systemu finansowego. Domagał się także reformy ubezpieczeń oraz rozwijania polityki innowacyjnej oraz zwiększenia inwestycji w oświatę i szkolenia. Ważnym tematem spotkania partii w Rostoku była polityka energetyczna ${ }^{86}$.

Po zjeździe w Rostoku polityka Westerwelle odbierana była jako zmierzającą na lewo. Spotkał się z zarzutami, że brakuje mu woli reform i za mało dba o politykę ochrony środowiska ${ }^{87}$.

Podczas gdy po wyborach spadało poparcie chadecji, FDP cieszyła się większą akceptacją, nie tylko wśród wyborców, (przybyło 4400 nowych członków partii od 2005 do czerwca 2007 roku). Również pozytywnie

${ }^{81}$ G. Westerwelle, 18..., op. cit., s. 31.

82 "Arbeit hat Vorfahrt- Deutschlandprogramm 2005", http://archive.org/details/ArbeitHatVorfahrt

83 "Guidos Preises", „WirtschaftsWoche”, 11.05.2009.

84 "Gestörtes Verhältnis", Der Spiegel", nr 40/2006.

${ }^{85} \mathrm{http}$ //57.parteitag.fdp.de/files/94/BPT2006-Rostock-Rede-Westerwelle.pdf

${ }^{86}$ Ibidem.

87 "Alles fließt”", „Der Spiegel”, nr 45/2006. 
o liberałach wypowiadał się Ludwig Georg Braun, prezydent DIHK (Deutscher Industrie- und Handelskammertag- Zrzeszenia Niemieckich Izb Przemysłowo-Handlowych). Westerwelle był zdania, że Chadecja powinna dostrzegać w jego partii „siłę rezerwowa, a nie niebezpieczeństwo ${ }^{88}$.

„Der Spiegel” podawał, że Westerwelle odnalazł się w roli lidera opozycji, był zadowolony z odniesionego wyniku wyborczego 9,8\%.Oceniany jako polityk stanowczy, pewny swoich przekonań, programu. Partia w 2007 roku uzyskała poparcie społeczne rzędu 11\% (Emnid), 11,5\% (Allensbach), $13 \%$ (Forsa) $^{89}$

Podczas zjazdu FDP w Stuttgarcie w dniach 15-17 maja 2007 Westerwelle został ponownie przewodniczącym otrzymując $87,6 \%$ poparcia ${ }^{90}$. W 2008 roku liberałowie świętowali sześćdziesięciolecia partii w Heppenheim. Grono liberałów powiększyło się o 6000 nowych obywateli. Był to czas przygotowań do superroku wyborczego 2009. Centralą wyborczą miał zarządzać Hans-Jürgen Beerfeltz ${ }^{91}$.

Westerwelle związku ze zbliżającymi się wyborami w Hesji zapowiedział, że liberałowie dopiero latem wskażą potencjalnego kandydata do formowania rządów po wyborach. Przez pierwszą połowę roku będą obserwatorami. Zamysł ten był zgodny z wolą Julis (Młodych Demokratów) ${ }^{92}$.Już wtedy jednak aktywność Westerwelle w partii była widziana jako "One-Man-Show”. Lider był za taki styl pracy krytykowany m.in. przez W. Gerhardta ${ }^{93}$.

W Stuttgarcie, podczas tradycyjnego zjazdu partii w święto Trzech Króli,6 stycznia 2009 roku, G. Westerwelle obiecał poprowadzić partię do zwycięstwa ${ }^{94}$. Wiele uwagi poświęcono kryzysowi gospodarczemu. W dyskusjach o sposobach wyjścia z kryzysu G. Westerwelle sprzeciwiał się nadmiernej pomocy ze strony państwa, czemu dał wyraz w trakcie debat o sytuacji firm Opel i Arcandor ${ }^{95}$.

W 2009 roku na zjeździe w Hanowerze liberałowie byli dość powściągliwi w wyrażaniu opinii. Ten zjazd został odebrany jako mniej demokratyczny niż wcześniejszy zjazd Zielonych. W „Die Zeit” pojawił się zarzut,

88 "Die gelbe Gefahr", „Der Spiegel”, nr 25/2006.

89 "Die Gegenstimme”, „Der Spiegel”, nr 27/2006.

90 "Krönungsmesse für Westerwelle”, „Die Zeit”, 15.05.2009.

91 "Die Liberalen sind weiter auf Erfolgskurs", http://fdp.de/webcom/show_article. php/_c-459/_nr-992/i.html

${ }_{92}^{2}$ S. Averesh, Union debattiert über Koalition mit den Liberalen FDP legt sich im Sommer fest, http://www.berlinonline.de/berliner-zeitung/archiv/.bin/dump.fcgi/2009/0105/politik/0056/index.html

93 "FDP-Parteichef kritisiert seinen Kritiker", http://www.berlinonline.de/berlinerzeitung/archiv/.bin/dump.fcgi/2008/0104/seite1/0103/index.html

94 "Mit starken Worten in Richtung Macht", "Die Zeit", 6.01.2009.

95 "Steinbrück hat ein Fiasko angerichtet", "Frankfurter Allgemeine Zeitung", 6.06.2009. 
że FDP bojąc się spadku sondaży przedwyborczych postanowili w Hanowerze mało krytykować, zadbać o dobrą autoprezentację. Liberałowie na zjeździe nazwali socjaldemokratów winnymi złej sytuacji gospodarczej. Politycy z FDP uważali, że dla ich partii najlepszym rezultatem zaplanowanych na wrzesień 2009 roku wyborów będzie utworzenie czarno-żółtej koalicji. Ich celem był koniec wielkiej koalicji. Westerwelle podkreślał, że FDP zależy na uniknięciu koalicji SPD, Zielonych i Partii Lewicy ${ }^{96}$

Podczas zjazdu w Hanowerze Westerwelle ponownie został przewodniczącym partii. Poparło go 599 głosujących, 18 było przeciwko, a 8 się wstrzymało. Wcześniej tak dobry wynik osiągnął w 1972 roku Walter Scheel. Zastępcami G. Westerwellego zostali - Rainer Brüderle z Rheinland Pfalz oraz Andreas Pinkwart z Północnej Nadrenii Westfalii, Cornelia Pieper z Saksonii Anhalt. Funkcję skarbnika objął Hermann Otto Solms, a sekretarza generalnego Dirk Niebel ${ }^{97}$.

Program wyborczy liberałów nosił tytuł „Praca musi się znowu opłacać”. W sprawach gospodarczych Westerwelle miał jasne stanowisko: „nie ma czegoś takiego jak prawo do lenistwa, opłacanego przez państwo [...], płaca minimalna to NRD, tylko bez muru (....), jeśli Niemcy są kapitalistyczne, to Kuba jest demokracją" ${ }^{\prime 98}$. Wypowiadał się o FDP, że nie jest partią neoliberalną, lecz partią będącą „ostatnim obrońcą socjalnej gospodarki rynkowej"99, dla której istotna jest „klasa średnia”"100. Krytykował Angelę Merkel i Peera Steinbrücka za bezradność wobec kryzysu gospodarczego. Za problemy gospodarcze Niemiec obciążył rządy lewicy - Oskara Lafontaine, Hansa Eichela i Peera Steinbrücka ${ }^{101}$.

Podczas zjazdu partii, w dniach 15-17 maja 2009 liberałowie zaprezentowali program „Wzmacniać środek. Program niemiecki Wolnej Partii Demokratycznej". FDP zapowiedziała odejście od funkcji partii języczka u wagi. FDP profilowała się na partię całego ludu, a nie partia ludowa (Volkspartei). W polityce międzynarodowej liberałowie potwierdzili wolę umacniania dobrych relacji z USA, integracji europejskiej, umacniania relacji z Rosją. Akcentowali znaczenie troski o bezpieczeństwo międzynarodowe ${ }^{102}$.

${ }^{96}$ M. Schlieben, FDP-Basis kritisiert "herzlose" Parteiführung, http://wwwzeit.de/ online/2009/21/fdp-parteitag; "Krönungsmesse für Westerwelle”, http://www.zeit.de/online/2009/21/fdp-westerwelle-wahlprogramm

97 "Westerwelle als Parteichef wiedergewählt", http://www.zeit.de/online/2009/21/westerwelle-parteichef-wiedergewaehlt

98 „G. Westerwelle”, „Forum”, nr 38/2009.

99 "Steinbrück hat ein Fiasko angerichtet”, „Frankfurter Allgemeine Zeitung", 6.06.2009.

${ }^{100}$ Ibidem.

101 Ibidem.

102 „Die Mitte stärken. Deutschlandprogramm 2009. Programm der Freien Demokratischen Partei zur Bundestagswahl 2009 beschlossen", http://www.deutschlandprogramm.de/webcom/show_article.php/_c-1213/_nr-4/i.html 
Wybory odbyły się 27 września 2009 roku. Ich wynik, korzystny dla liberałów, (otrzymali 14,6\% poparcia), wskazywał na przeobrażenia w systemie partyjnym Republiki Federalnej Niemiec. Porażkę odnotowały CDU/CSU i SPD, natomiast lepiej uplasowali się Zieloni i Partia Lewicy ${ }^{103}$. Chadecja opowiedziała się za prowadzeniem rokowań koalicyjnych z liberałami, czego nie chciała uczynić ani w 2002 roku, ani w 2005 roku $^{104}$.

Guido Westerwelle, podobnie jak wcześniej Genscher i Kinkel, został ministrem spraw zagranicznych w gabinecie Merkel. Swoje relacje z kanclerz Merkel określił jako dobre. „Angela Merkel i ja jesteśmy partnerami i też w polityce zagranicznej. Ten rząd nie jest małżeństwem z przymusu jak Czarno-Czerwony, lecz wymarzoną koalicją. Sukcesy są wspólnymi sukcesami"105. Rozważono dla niego tekę albo ministra gospodarki albo ministra spraw zagranicznych, rola tradycji. FDP wraca do rządu ${ }^{106} .26$ października 2009 roku został zawarty między chadecją i liberałami układ koalicyjny: „Wzrost. Oświata. Spójność". Liberałowie wprowadzili do rządu 5 ministrów. Byli to obok Westerwelle, liberał Philipp Rössler jako minister zdrowia, minister sprawiedliwości Sabine Leutheusser-Schnarrenberger, minister gospodarki Rainer Brüderle, Dirk Niebel-ministerstwo rozwoju ${ }^{107}$. Zastanawiano się, jako będzie współpraca z ministrem obrony Karlem Theodorem zu Guttenbergiem.

Niepowodzenie i ogromna krytyka społeczeństwa spotkały Westerwelle, gdy w lutym 2010 roku wypowiedział się na temat sytuacji społecznej w RFN na forum „,Die Welt”. Lider FDP stwierdził wtedy: „kto obiecuje narodowi dobrobyt bez wysiłku, zaprasza do późnorzymskiej dekadencji" i krytykował beneficjentów HARZ IV"108

Klęska liberałów podczas wyborów w Badenii Wirtembergii i Rheinland Pfalz została potraktowana jako „początek końca ery Westerwelle”109. Pojawiły się obawy o rezultat przewidzianych na 11 września 2011 roku wyborów w Dolnej Saksonii. Najpierw krytykowali polityka liberałowie z "drugiego szeregu” - Michael Roolf z Mecklemburgii Pomorza Przed-

103 „Bitter Tag für die Sozialdemokratie”, http://www.sueddeutsche.de/politik/bundestagswahl-bitterer-tag-fuer-die-sozialdemokratie-1.26679

104 „Gelb-Gelb-Schwarz", http://www.sueddeutsche.de/politik/die-fdp-nach-der-bundestagswahl-gelb-gelb-schwarz-1.32036

105 "Interview mit Bundesaußenminister Guido Westerwelle in der Bild vom 07.11.2009", http://www.auswaertiges-amt.de/DE/Infoservice/Presse/Interviews/2009/091107-BM-Bild. html

106 P. Jendroszczyk, Dyplomata na nowe czasy, "Rzeczpospolita”, 3.10.2009; P. Cywiński, Wicekanclerz z małżonkiem, "Wprost”, 11.10.2009.

107 "Dezimieren und domestizieren", "WirtschaftsWoche”, 30.11.2009.

108 G. Westerwelle, "An die deutsche Mittelschicht denkt niemand", ,"Die Welt”, 11.02.2010.

109 "Aufstand der Verführten", „Der Spiegel”, nr 14/2011. 
niego wypowiadał się, że FDP potrzebuje odnowy i nowych liderów. Jorgo Chatzimarkakis zasiadający w Parlamencie Europejskim też domagał się zmian. Długo milczeli czołowi politycy - sekretarz generalny Christian Lindner, Phillip Rösler, Sabine Leutheusser-Schnarrenberger.

62. Zjazd FDP w Rostocku w dniach 13-15 maja zdominowały problemy partii. FDP odnotowała spadek poparcia z 14\% w 2009 roku do 5\% w 2011 roku. W domysłach Westerwelle mógł być zastąpiony przez Ch. Lindnera lub P. Röslera. Zwyciężył P. Rösler uzyskując 95,1\%. Niemiec wietnamskiego pochodzenia. Rösler opowiedział się za wizją FDP jako „partii środka"110. Westerwelle natomiast wraz z utratą przewodnictwa w FDP utracił funkcję wicekanclerza ${ }^{111}$.

$Z$ rezygnacji Westerwelle wyraził zadowolenie Genscher. Gerhard Baum, były minister spraw wewnętrznych upatruje w Westerwelle źródło „problemów partii twierdząc: „on personifikuje głęboki kryzys zaufania, w który popadła FDP"112

\section{Zusammenfassung}

Der Artikel beschreibt die Bedeutung von Guido Westerwelle für die Freie Demokratische Partei und seine Präsenz in der deutschen Politik. Guido Westerwelle repräsentiert eine Epoche in der Geschichte der Freien Demokratischen Partei und war in den Jahren 2001 -2011 ihr Bundesvorsitzender. Nach Theodor Heuss, Walter Scheel und Hans-Dietrich Genscher versuchte er den deutschen Liberalen ein neues Gesicht zu geben. Die wichtigsten Quellen meiner Forschung sind Dokumente der Freien Demokratischen Partei, von Guido Westerwelle geschriebene Bücher, Biographien dieses Politikers und die Presse.

110 „Die FDP soll wieder kämpfen”, „Die Zeit”, 14.05.2011.

111 M. Feldenkirchen, Der Geduldete, „Der Spiegel”, nr 20/2011.

112 "Aufbruch in Bleitweste", „Die Zeit", 14.05.2012. 